
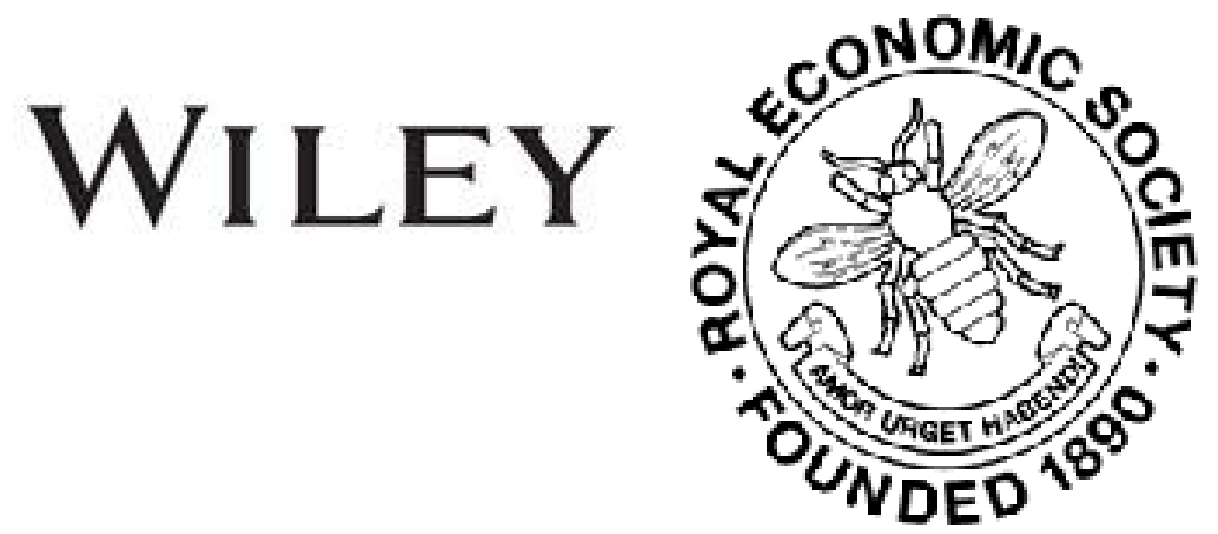

\title{
Economic Conditions in Ancient India
}

Author(s): C. A. F. Rhys Davids

Source: The Economic Journal, Vol. 11, No. 43 (Sep., 1901), pp. 305-320

Published by: Wiley on behalf of the Royal Economic Society

Stable URL: http://www.jstor.org/stable/2956664

Accessed: 06-06-2016 03:44 UTC

Your use of the JSTOR archive indicates your acceptance of the Terms \& Conditions of Use, available at

http://about.jstor.org/terms

JSTOR is a not-for-profit service that helps scholars, researchers, and students discover, use, and build upon a wide range of content in a trusted digital archive. We use information technology and tools to increase productivity and facilitate new forms of scholarship. For more information about JSTOR, please contact support@jstor.org.

Wiley, Royal Economic Society are collaborating with JSTOR to digitize, preserve and extend access to The Economic Journal 


\title{
THE ECONOMIC JOURNAL
}

\author{
SEPTEMBER, 1901
}

\section{ECONOMIC CONDITIONS IN ANCIENT INDIA.}

TILL within the last quarter of a century, the economic historian, when coping with the subject of early civilization in the East, was no better off than the early Israelite, who was ordered to make bricks and given no "straw." With the exception of the Semitic literature of the Near East, he was almost without historical data. Professor Cossa has defined the history of political economy as "the reasoned narration of the origin and progress of economic theories considered in relation to conditions, ideas and social institutions." But if a given epoch be very remote, the theories may not have attained to distinctive expression, and nay have to be dug out of relatively unspecialized records. Again, the social conditions must be known if they are to be related to the theories. And the economist, looking around for his data as extracted and collated by specialists, often goes bungry away and writes down the age as "epoca frammentaria."

Of ancient India in particular, it is but since yesterday that early records bave to any large extent begun to be accessible. Nor has the literature now opened up to readers of English yet been sifted for evidence as to the economic institutions, much less the economic theories, which prevailed within the area and during the epoch of its growth. No one as yet has compiled from it what Professor Cossa would term "discipline economiche storico-descrittive," such as August Boeckb attempted in his Staatshaushaltung der Athener. "Fragmentary" as the data may be, they are still ungathered into baskets. Hence, although the distinguished economist quoted above gave the world his Guida, re-written and enlarged into the Introduzione, as late as 1890 , be No. 43.- vol. XI. 
was unable to throw any new light on to Eastern economic history. The contents of that one solitary paragraph entitled "Oriente" are so meagre and shadowy that we are left very much where readers of Niebuhr's Lectures on Aneient History found themselves, when under India they found a blank left unfilled with a purpose. The authorities cited are all too superannuated, as neo-Oriental learning reckons, to supply such data as were even ten years ago available to the monographist.

It is true that in having failed, so far as. we know, to produce historiographers and dramas, ancient India as compared with ancient Greece suffers heavily in her supply of economic ore. Archæological discoveries, too, are still largely to make, owing chiefly to our curious national supineness about matters calling on the historic imagination. On the other hand there are now ready to hand some compensating treasures. Since the year 1879 , in the first place, in the series of the Sacred Books of the East, there have been published a considerable number of so-called law-books, or text-books on conduct and custom taught, at the date of compilation and after, in various ecclesiastical colleges, to young Indian laymen. That date ranges, in the case of the older books, from B.C. 300, if not earlier, to A.D. 1; the law-book known generally by the name of Manu dates between B.c. and A.D. 200; and the later law-books are assigned to the fourth or fifth centuries A.D. Here we have manuals, written by Brahmanic priests with a keen eye to the spiritual and material interests of their class, yet from which, if this personal, or rather corporate equation be discounted, many hints may be gathered respecting trades and taxes, exchange and credit. ${ }^{1}$

In the next place the last twenty years have witnessed the publication in English or German of a large part of the original Buddhist canonical works, the compilation of which is assigned to the fifth and fourth centuries B.c. Here, again, the standpoint is that of the religious fraternity, the object, that of religious philosophy. But it is not a philosophy of the armchair or of the cell, but of the open air and of the daily life of men in touch with their lay fellows. Hence incidentally there are to be found illustrations of social institutions.

Much more is this the case in the great thesaurus of folklore - the parent of much of our own mediæval fiction-which was

1 Investigation into the political institutions revealed by these law-books has been already set on foot in such monographs as Dr. Foy's Die Königliche Gewalt nach den altindischen Rechtsbiichern, and Dr. Carlo Formichi's Gl' Indiani e la loro scienza politica, Pt. I. 
incorporated into the Buddhist canon as the Jâtaka, or Re-birthStories, and of which two-thirds have already been translated into English. Folklore is of course not good statistics ; incidentally and accidentally, however, these hundreds of tales with their introductory episodes, serve to illustrate, if not the times to which they refer, at least the times when they were definitely compiled and incorporated. In other words, they may be consulted for evidence of social usages prevailing in Northern India between the sixth or seventh centuries B.c. and the date of the Emperor Asoka, who reigned about fifty years later than Alexander the Great. ${ }^{1}$

Nor is the recent accession of material exhausted by the works. named above. Among the volumes of the Sacred Books of the East there are the Questions of King Milinda (Menander of Bactria) and assigned to the first centuries A.D., containing references to economic usage. And, to revert to an earlier age, there are also the volumes entitled the Shata-patha-brâhmana, or orthodox exegesis of Brahmanic ritual, a compilation dating from about B.c. 800. The subject does not sound promising for the economist, and yet, as will be seen presently, the work contains passages of special interest on the methods of purchase then current.

Such are some of the more noteworthy records of ancient India which have been added to the materials awaiting historical investigation since the day when the oldest of all Indian literature-the Vedic-began to woo the cramped affections of European scholars. That literature has already, to some extent, been analysed for what it reveals of Aryan society in Zimmer's Alt-indisches Leben. And for what remains, nearly every year sees the publication either of the translation of some ancient record, or at least of its transcription from palm-leaf manuscript into book form. To attempt here and now a complete economic survey or special monograph from these materials is not feasible. But the attempt may reasonably be made to show that, given the greater insight now afforded into the economic institutions prevailing in the valley of the Ganges during the last six centuries of the pre-Christian era, it is possible to make a better contribution to the history of political economy than is afforded by the antiquated works which have guided Professor Cossa in his brief section "Oriente."

1 Dr. Fick's pioneering monograph Die sociale Gliederung im Nordöstlichen Indien zu Buddha's Zeit is a valuable example of the sociological importance of the Jâtaka, the writer having drawn his materials almost wholly from this work. 
Let us first consider what is there affirmed concerning "the economic ideas of the peoples of the ancient East." They are said (1) to be reducible to a few ethical precepts, and (2) to extol agriculture and to decry arts and commerce. And concerning economic institutions we are told (3) that, whereas agriculture flourished, division of labour, though politically free, stiffened into a system of hereditary caste and arrested economic progress. (4) Any insight into the nature of money and its " fiduciary surrogates" is credited to the Chinese alone, and to them no earlier than the seventh century A.D.

Now I should like to monopolise the pages of the Economic JoURNaL just long enough to indicate that these four points, viewed by the light of materials now accessible, are shown, so far as ancient India is involved, to require serious modification.

I do not propose to harass the reader with giving chapter and verse for every detail of economic evidence brought forward. All, unless it is stated otherwise, are drawn from the materials now made accessible to which I have referred above. That this is so, the reader who wishes to do so may verify, by consulting an article in the October number of the Journal of the Royal Asiatic Society, the object of which is the presentation of a quantity of classified economic material from early Indian literature.

Let us briefly consider first the rural economy, and next the commercial development of the peoples dwelling on the Ganges and its tributaries, both before and at the time when Megasthenes was residing as ambassador at Pâtaliputta (Patna), i.e. about B.c. 310. Over this great area no paramount sovereignty had till then been established. It was divided into some half dozen monarchies and a few aristocratic republics (Sākyans, Koliyans, Licchavis, \&c.), where every clansman was termed a raja. Such had been the issue and development of the influx of Aryans from the north-west who had subdued and assimilated the Dravidians and the Kolarians, their precursors in civilization. This congeries of states had maintained a political equilibrium-a pax indica of balanced powers-till Alexander had come disturbing as far as its western limits. Frustrated on the Indus, and unheeded by contemporary Indian literature, his ideal of empire fructified in one of these monarchies of the Ganges-that of Magadha (Bihar) - and culminated in the empire of Asoka. But agriculture and commerce did not wait upon empire to develop to any striking extent the considerable degree of organization to which they had already attained. 
Rural economy was based on the system of village communities of land-holders, not on that of feudal landlords. We nowhere read of isolated houses, or of great lords of the soil, lay or ecclesiastical, owning farms and serfs. The kings are never mentioned as interfering with rights of tenure. In return for giving political protection, they levied a tithe on the raw produce-chiefly rice and cattle-of each village, varying between a tenth and a sixth. ${ }^{1}$ And this tithe, in the case of one or more villages, they are often represented as making over to queens or commoners; but never the villages nor the soil is thus bestowed. No ancient records give any systematic account of this rural economy, but it is impossible to read of the many illustrations of it in the Buddhist books without being reminded of some characteristics of modern communities of peasant proprietors, those of Alpine districts, for example. Dwellings appear to be always in groups; near by the sacred grove of primeval forest is left intact; this excepted, all around stretches the communal field with a ring fence to keep off marauding animals, but no inner fences, the boundary of each householder's plot being the channels dug for purposes of cooperative irrigation. The Buddha is recorded to have beheld "how the Magadhese arable land was divided ray-wise and in rows and by outside boundaries and by cross boundaries," and ordered it should serve as a pattern for the "khaki" patchwork robe of his fraternity (Sacred Books of the East, XVII., 207, 208). There was also the common grazing ground, where the cattle roamed under the charge of the communal cowherd who managed the co-operative "laiterie." And just as Alpine peasants agree to contribute by rote so many days' work during the year to maintain their roads, so .we find, in the Jâtaka stories (I., No. 31), the thirty householders of a Magadhese village cooperating not only to keep their four highways and their byways cleared and in repair, but also to build a vestry hall and resthouses and to dig reservoirs. Certain women insisted on contributing their share of work and expense; and their king is described as remitting the royal tithe. Another instance of corporate initiative is that of enclosing a royal hunting preserve and handing it over to the king, so as to protect the village field from the inroads of game (I., No. 12 ; III., No. 385). We meet with the village crop of grain amassed in "the granary," and the chief revenue officer supervising the measuring off of the

1.This was not changed under the empire. On the pillar, lately discovered at Rummin Dei, is inscribed the remission in perpetuity of the tithe of one-eighth to commemorate the pilgrimage thither-to the birth-place of the Buddha-of Asoka. 
royal tithe (II., No. 276 ; IV., No. 467). But the records are not clear as to whether the remainder was taken away to private barns or left here; or whether the granary thus mentioned served for that reserve store of grain in case of emergency, which was made universally and from time immemorial in India until about the middle of the last century. ${ }^{1}$ That famine, or at least local scarcity through drought was well known is clear from the Buddhist records. ${ }^{2}$

Such, in very brief and meagre outline, were the salient features in the ancient rural economy of northern India. The cultivation of few or many karîsas of arable land did not, any more than did the possession of few or many cows, necessarily monopolize the whole time of the family. Industry was so far specialized and localized that we not seldom read of villages of carpenters, of ironsmiths, of backwoods villages of trappers, and of villages of brahmins, i.e., of men claiming through heredity the monopoly of sacred lore and sacrificial celebrations. But there is no indication that these specialized groups derived the means of existence entirely through the exchange of their own produce or services with dealers, or through fees from without. On the contrary, brahmins appear frequently in the Jâtaka stories as cultivating their own acres, aided sometimes by their families and slaves or hired labourers. And in at least one case such a person, owning a thousand karîsas, is described as living in a brahmin village. (Jâtaka, Vol. IV, No. 484). There were, however, brahmins and brahmins. Those who took their hereditary sacerdotal functions seriously undertook no worldly calling, abstaining from agriculture as much as from hunting, trade or usury. This appears already in the folk stories. ${ }^{3}$ - But the lawbooks expressly reserve the callings of agriculture and trade for the middle class or, as they phrase it, the Vaisya Colour alone, as unfit for either the nobles (Kshatriya Colour) or brahmins. The latter might only engage in them either in distressful circumstances or if they took no active part in the work (Sacred Books of the East, II., 123, 225, 229 ; XIV., 11, 175, 176 ; XXV., 272, 325). Agriculture, then, was all very well as a trade among trades, but there is nothing in the records of the era in question to show that it was

1 The inscriptionoin Asokan character on the so-called Sohgaura plate, discovered a few years ago in Nepal by Mr. Hoey, shows that the plate was affixed to the door of an emergency grain-store.

2 Megasthenes was told that a "general scarcity" was unknown, which possibly was not incorrect. (MacCrindle, Ancient India as described by Megasthenes, p. 2.)

3 Jat., Vol. IV., No. 495, "Some follow trade and husbandry . . . . lost is their brahminhood." 
regarded as more dignified than what is specifically understood as trade. It is considered unfit, in the brahminical tradition, for the ruling and learned classes. As involving a certain amount of destruction of animal life, it could not rank high in the tradition of Buddhists or Jains. Nor in those law-books where it is prescribed for certain classes, is it to them recommended as superior to other prescribed callings. In the earliest Indian literature, the Vedas, it is well known that agricultural and pastoral concepts play a great part. But even if this involved a special dignity ascribed to agriculture, as well as the more certain implication of its being the main industry of the Aryans, it does not follow that such a tradition continued through the post-Vedic era. There was among them nothing of that feudal tie between land and lord, with lordship over the land-tillers, that made broad acres a basis for nobility in the West. However the Aryans may have compassed their invasion of the Ganges valley, land-grabbing does not seem to have been carried out in any proportion to success in generalship. This may have been so because annexation of land meant to a large extent, as it does even to this day, clearing of land, i.e. of the jungle. Except for the Dravidian and Kolarian settlements along the rivers, the task of the Aryans was more like that of pioneering squatters in America. And there we know that land is not an appanage involving special privileges and duties, but a commodity like any other.

We will now see what may be gathered respecting the contemporary state of industry and commerce, giving especial heed as to the effect on their development of the evolution of "caste."

It may be affirmed as approximately true that the great bulk of the inhabitants of ancient Northern [India lived under the conditions of rural environment just described, without riches or poverty, without landlords or paupers. In all the stories and episodes contained in the Buddhist canonical books, barely a score of towns are mentioned by name, though the area alluded to is about $600,000 \mathrm{sq}$. miles in extent. At the same time some at least of these are expressly called "great cities." By this was understood not only the central mass of dwellings with a royal residence with "terraces" and open courts, extensive mews and pleasure grounds, but also suburbs extending on every side, and, in the immediate neighbourhood, centres of localized industries, for woodwork, ironwork and pottery, for instance. Industries were also grouped within the towns themselves, as in European economy, mention being made of an ivory-workers' street, a 
dyers' street and the like. Up to the age of Gotama Buddha, i.e. the sixth and fifth centuries B.C., the chief industrial and commercial centre was Benares, which seems to have had a practical monopoly in the production of the famous muslins and silks. After that date Patna began to advance as a great emporium, and, under the empire, became the imperial residence. Communication, both inland and foreign, was of course effected by caravans and by water. The former are frequently brought into the folk-lore. They are described as consisting of the, so to speak, symbolical number of 500 carts drawn by oxen, the merchant himself travelling along in a special car, and the caravan, as often as not, convoyed through the jungle by a body of voluntary constabulary, engaged at a fixed money-fee to keep off robbers. Their route seems to have been usually from east to west, and across deserts that took days to cross and for which a "land pilot," steering during the cool of night by the stars, was required. The objective was probably the ports on the west coast:-those on the seaboard of Sovira (? the Sophir [Ophir] of the Septuagint), in the Gulf of Cutch, or Bharukaccha, i.e. the modern seaport of Baroach. From here there was interchange by sea with Baveru (Babylon) and probably Arabia, Phenicia and Egypt. The deserts would thus correspond to the great desert of Rajputana. From Sindh, too, and from " the North," horses were imported to the Ganges valley. Westward, merchants are often mentioned as taking ships from Benares, or, lower down, at Champâ (Bhagalpur), dropping down the great river and either coasting to Ceylon, or adventuring, many days without sight of land, to Suvannabhûmi (Golden-soil, Chryse Chersonesus, or possibly inclusive of all the coast of Further India). The vessels seem to have been constructed on a fairly large scale, for we read of them carrying "hundreds" of merchants or of emigrants. The numbers given in the folkstories are of course worthless; but the current conceptions revealed in them may count for something.

Now in passage (3) of Professor Cossa's section " Oriente," it is affirmed that labour, in spite of "liberty," stiffened and crystallised into hereditary castes, which impressed on Oriental civilization the character of immobility. The ancient records do not warrant any such conclusion. They go far to show that (i) whereas there was, in industry and commerce, little liberty in the sense of absence of organization, (ii) there was no such thing as a hard and fast division of the industrial world into hereditary groups or castes, but on the contrary there was a considerable degree of mobility both of labour and capital. 
In all probability there was scarcely a single trade or calling but was organised as a gild (seni) with its own special rules and its acknowledged head. Master mariners, literally navigators, had also a recognised chief, so too had the profession of caravan constabulary, and, within the merchant profession, that of caravan leaders. Professor Hopkins, writing, a dozen years ago, ${ }^{1}$ of Indian gilds, holds it an "early" reference to find them and the political validity of their corporate regulations mentioned in Manu. But the Buddhist books leave no doubt of their existence some centuries earlier. The "gilds" are frequently mentioned as a leading factor in the body politic summoned by and attending upon the king, either en masse, or through their heads or representatives who were apparently permanent court officials and even "great ministers." One of the Jâtaka stories records the inception of further organization in the appointment of a permanent president over all the gilds vested in the person of the lord of the treasury (Jît., IV., No. 445). The leading gilds are spoken of as eighteen in number, "to wit, the Carpenters, ${ }^{2}$ Smiths, Leather-workers, Painters and the rest." Of their special regulations we have as yet no evidence to show. Apprentices are often mentioned, but not the terms of apprenticeship. But that the gild as a body exercised a quasi-paternal control over its members is evinced by the ordinance of the Buddhist church, which forbade the giving religious orders to the wife of a member unless his gild had sanctioned it. ${ }^{3}$

This tendency of the Indian to mutual organization-in which he resembled his later kinsmen the Western Aryans of the Middle Ages-found further expression in the general institution still in force, of a headman or syndic in every village. And when the village consisted of the craftsmen of one localized industry, the functions of syndic and president of the local gild would be doubled in the same person. Such a functionary might attain a high social status, for instance, the "elder" of a village of 1,000 smiths is described as " a favourite of the king (of Benares), rich and of great substance" (Jâtaka, III., No. 387).

The foregoing corporations are all "craft-gilds." The contemporary literature does not warrant the conclusion that the class of merchants or middlemen was organized in the same degree. Industrial organization was, and is, largely based on the

1 “"Position of the Ruling Caste in India," J. Amer. Or. Soc, 1889.

2 Vaddhako includes all forms of wood-work-joiners, cabinet-makers, shipwrights, cartwrights, \&c. Jataka, VI., pp. 22, 427 (of the text).

3 From the Sutta Vibhanga, a work yet untranslated. 
circumstance of neighbourhood. The merchant was necessarily a wanderer. His corporate institutes, if he had any, would take effect in highly developed markets and at seaports. Nevertheless, as has been stated, caravan traders had their cbief. Localization is at all events betrayed in the phrases- "the Vaisyas' street," "the bourgeois quarter" (Jâtaka, VI., p. 485. of the text ; Fick, op. cit., 180 n).

Combined with this widespread corporate regulation of industrial life, there was unquestionably the tendency for the son to follow the father's craft. Nothing is more common throughout the Buddhist narratives than to find families characterized by their hereditary craft, and craftsmen called by their father's craft, e.g., Smithson as = Smith. This, however, is not peculiar to India, but especially characteristic of all Aryan societies at, or up to a certain stage of development. Even of our own it was said only 50 years ago that the line of demarcation between different employments or grades of work had till then been "almost equivalent to an hereditary distinction of caste." 1 In modern India, no doubt, these lines of demarcation have intensified in the course of centuries, and have split up the industrial world into a, to us, bewildering number of sections, or, as we call them, castes, which may well involve the economic drawbacks which some writers have fancied were especially characteristic of ancient India. But in that ancient India we can say with assurance that the caste-system, in any proper or exact use of the term, did not yet exist. What we actually find is caste in the making.

The origin of caste must be sought in the fact that when Aryans subdued and settled down along with Dravidians and Kolarians, the fusion of races stopped short at connubium and commensality. To determine how, from these beginuings, the caste system came to form a phase in the evolution of occupation, remains a sociological task of great interest. But the notion of a permanent immobility of social strata must be given up, not only as to the past, but even as to the present. Castes have been and are still being made by series of slight changes in public opinion not perceptible to surface observation. ${ }^{2}$

During the age with which the present article is concerned the majority of the people were roughly distinguished into four classes or social ranks which, owing to ethnological beginnings, were

1 J. S. Mill, II., xiv., 2.

$2 C f$. the modern instance described in Rhys Davids's Dialogues of the Buddha, I., 1899 , p. 98 , where the whole question is discussed at some length. See also Fick, op. cit., h. 10,11, on the subject of caste in general. 
called colours or complexions. These were the nobles, the priests, the remainder of the Aryans (Vaisyas) and certain nonAryan clans (Sûdras). Outside these, again, were certain aboriginal tribes (Chandâlas and Pukkusas) not confined to any one hereditary craft, and certain other such who did so confine themselves-rushworkers, trappers, cart-makers. All these are referred to as " low tribes," "low trades." Finally there were slaves, their servitude either due to conquest, debt, or crime, or else voluntary. They do not appear to have been maintained in large numbers, as in the West, in mines, farms or plantations. We find them engaged, few in number, as domestic servants and as a rule well treated.

But this division of colours conveyed, at the time of which I write, no import of any impassable barriers to economic mobility or progress. The law-books, written in the interests of priestly diplomacy, endeavoured to foster the pride of birth, which, in all countries, deters men from mingling freely with each other, and prescribed special pursuits for special "complexions." But in the Buddhist literature we find in actual life considerable freedom of initiative. A king's son cedes his share of the kingdom to his sister, turns trader and travels with his caravan. Brahmins work as husbandmen, as traders, as hunters, and as cartwrights. And the prince, whose wife in a fit of displeasure has returned to her father, apprentices himself in succession and without entailing subsequent social disgrace to the court potter, florist and cook, in order to gain access to her. Another, fleeing from his brother, hires himself to a neighbouring monarch as archer. The parents of another youth are represented as debating whether to let him enter the profession of a writer, an accountant, or of a money-changer, the father's profession or "caste" not being so much as alluded to. Another young man of good birth but penniless starts on his career by selling a dead mouse for a tavern-cat at one farthing, turns his capital and his hands to every variety of job, and finally buys up a ship's cargo on pledging his signet-ring as security, and realizes a profit of 200 per cent., winning with that the hand of the burgomaster's daughter. (This youth ought to have become president of the United States.) Once more we read of a village of carpenters who being paid in advance for orders they failed to carry out, were dunned. Instead of " abiding in their lot," as General Walker said of their descendants "with oriental stoicism and fatalism," 1 they made "a mighty ship," and emigrated, slipping

1 The Wages Question; p. 177. Jâtaka, IV., No. 466. 
down the river by night, and so out to sea, till they reached a fertile island. Stories, of course, not histories; nevertheless they serve to illustrate the degree to which labour and capital were mobile at the time when they were incorporated in the Buddhist canon, and before that time.

Enough has been said to show that social divisions and economic occupations were very far from coinciding. There was plenty of pride of birth which made marriage or eating together between certain ranks a disgraceful act to those reckoned socially as higher. And sons, especially among artisans, tended to follow the paternal industry. This was all.

And so far from there being any exclusiveness in ordinary intercourse between nobles, priests and commoners who had made or were making their fortunes in trade, we frequently find the sons of burghers the playmates and schoolfellows of princes and young brahmins.

Apart from certain "low trades" on which, either through their nature (butchering, for example), or through their monopoly by aboriginal tribes, a stigma rested, there was but one form of work that damned the doer in social esteem. This was to be a hireling. In the "greater family" a slave might receive even paternal treatment. But the hired worker, using other folks' capital and working for their profit, paid for his civic rights at the price of the citizen's respect. The only case of slave-beating in the Jâtaka is that of a slave-girl let out to work for hire, and who had not brought home her wage (Jût., I., No. 97). In a list of callings, in Buddhist books, the hired labourer, not the slave, ranks among the lowest, among hewers of wood and flowergatherers. And the prospect of peasant proprietors toiling on the estates of royal capitalists forms part of a prophecy of social decay: (Questions of Milinda, II., 209, 210 ; Jât., I., No. 77.)

I come to my last point-the methods of exchange in use in ancient India.

In the Vedic age-usually fixed roughly in the centuries dating from B.c. 2000-all exchange was by way of barter. But there was an approximation to a common standard of value in the shape of so many cows. Bargains were determined not by political or municipal authorities or body of dealers fixing prices in terms of bovine or other value, but by the particular "haggling" at each transaction. The Rig Veda has an interesting, if obscure passage, ${ }^{1}$ depicting the mutually unsatisfied

${ }^{3}$ X., xxiv., 9. Cf. Zimmer, Alt-indisches Leben, 258. 
greed of buyer and seller departing without coming to terms.

Coming to the post-Vedic or Brâhmana period, we still find that custom and theory (if one may so call it) prescribed the free bargain. In the Shata-patha Brâhmana, described above, we read that the form of haggling gone through in exchanging a cow for the soma juice required in sacrifice, is declared (hysteron proteron) to be the sanction not only for the vendibility of "any and every thing in this country," but also for the custom of "first bargaining and then coming to terms" (arvâk panante parah sampâdayanti). That soma was bought with a cow may by this time have become a conservative survival characteristic of religious ritual. For whereas in Vedic times the transition to money payment was being prepared by the custom of giving so many nishkas or góld ornaments as gifts, ${ }^{1}$ in the work just quoted, there is mention of the laity paying the priests with a fee of gold pieces each of a certain weight.

Now if $\dot{w}$ e let 1,000 years elapse and consult the law-book known as Manu, we find that, whatever was actually the current practice, economic theory had touched the opposite extreme with regard to the act of exchange. Thus (VIII.; 401, 402) :- " Let the king fix the rates for the purchase and sale of all marketable goods, having considered whence they come, whither they go, how long they have been kept, the profit and the outlay. Once in five nights, or at the close of each fortnight, let the king publicly settle the prices for the merchants."

With regard to the medium of exchange, too, all values in Manu are estimated in terms of money, including, of course, the current rate of interest. But the use of money was well developed long before Manu, together with such initial steps in the use of "fiduciary surrogates" as are possible without banking or political control of circulation.

The Buddhist books cannot be said to contain any statement of a theory of exchange. But there is also no indication that monarchs or other authorities "settled the prices for the merchants." Prices seem to have been settled, relatively to each other, very much by custom, with a range of market fluctuation ( $J a ̂ t$., I., No. 1), and, in the case of scarcity values, on the zest of the purchaser. "My wife is at times as meek as a slave girl bought for 100 pence," reveals probably a customary price. In the wellknown story of the Jetavana monastery the wealthy merchant buys the site at the fancy price demanded, viz., by laying down

1 Zimmer, op. cit., 259. Sacred Books of the East, XXVI. 69 ; XLIV., 275. 
coins so as to cover the soil-a story which, on a lower ethical scale, has its counterpart in modern times. A court valuer, termed the aggkakâraka or value-maker, plays a part in the Jàtaka, who inspects goods brought to the court, and fixes what it is worth the king's while to give. But he is not said to create the general market price thereby, although, in the evolution of the monarchy, he may have himself evolved into the Board of Price I have quoted from Manu (Jât., I., No. 5 ; IV., No. 463).

Nor is there any indication of any organization of the market comparable with the well-developed regulation in wealth-production. The few cities had their permanent appanas or shops, the keeping, literally spreading, of which is a mode of livelihood, and which are described as left open on the migration of a city population. And the great mass of the peoples, living in villages, no doubt held their weekly market on their respective borders with more or less of the gaiety of a fair as they do at the hath of today. There is no word in the ancient vernacular for marketplace, i.e. within the village or town. There is only mention of a central business-place, with or without a meeting-hall; also of cross-roads, and of wares-meat, e.g.-being sold there. ${ }^{1}$ 'But I have only found a term for market-place in a cumbrous phrase in a commentary of the fifth century A.D. - "a place for the distribution of commodities."

On the other hand there is no doubt but that the Buddhist literature reveals a society having the full use and enjoyment of a plentiful coinage. The worth of every marketable commodity, from a dead mouse and a day at the festival up to all kinds of fees, pensions, fines, loans, stored treasure and income, is stated in figures of a certain coin, or its fractions, and that is usually, either explicitly stated or implied to be, the kahâpana. ${ }^{2}$ Barter occurs only among the poor, the Buddhist Order, who were not perpnitted the use of money, and in wild regions. As a standard of value it is probable that rice was appealed to and not money, which is admitted to have varied locally in value (Jat., I., No. 5).

The nature of the kahâpana and its weight is matter for conjecture. But on the one hand we have the bas-relief on the Bharhut

J $C f$. the Dutch word for shop : winkel, which in German and Norwegian = corner, but from the inside (ingle). Translators have used "market-town" and " market-place" for Indian words which contain, etymologically, no reference to market.

${ }^{2}$ We read once or twice in the Jataka of gold coins or pieces-the masaka and the nikkha-cf. above nishka. 
stûpa ${ }^{1}$ ( supposed to have been erected before Asoka),illustrating the laying out of the coins, or square punched pieces of some metal. On the other there are certain ancient Indian coins in the British Museum which closely resemble these, and are of copper, nearly as heavy as pennies (150 grs.).' They have no date or inscription, but only a stamp, and are rather merchants' tokens than coins. But the narrative of the purchase of the monastery speaks only of " gold" brought and laid down, not of kahâpanas. India's wealth in gold, and her large export of it to Persia as early as the times of Darius Hystaspes are well known, and it is possible that she used to pay gold where we used to pay pennies. But the typical figure for a millionaire's wealth-800,000,000 (pieces) -amounts to $£ 3 \frac{1}{3}$ millions, even if we reckon kahâpanas as pence. Again, the daily dole of a typically benevolent king or millionaire was 1,000 (pieces) at each of his six almonries, and here it seems more probable that copper money was meant. ${ }^{2}$

There does not seem to have been any anticipation of modern banking. Individual deposits of money with friends are alone mentioned. But money was lent directly to a large extent, and debtor and creditor frequently appear in the Buddhist narrative. A debtor dunned by creditors may not be admitted into the Buddhist Order. Putting away hindrances to the higher life is likened to a man who, having contracted a loan to set a business on foot, pays off the debt, and marries on the surplus. The pushful youth, mentioned already, " dealt in futures" by borrowing on security. The "debt-sheet" (ina-panna), or promissory note, is often introduced in narratives, creditors confronting their debtors with it. In the Questions of King Milinda appears, by way of simile, the bankrupt making public statement of his assets and his liabilities. Again, the sight of a deposited security recalling the circumstance of the pledging is given as a typical form of mental association. Such a security might be a signet-ring, or a son, or what not. Of the form of the promissory note itself we have as yet no recorded description, such as exists of those used in ancient Greece.

I can quote no instances of any precise rate of interest demanded from the Buddhist books, but we find both the institution of interest and that of the usurer in a canonical

1 Illustrated in Cunningham's Stupa of Bharhut, and Coins of Ancient India. I do not know of any warrant for rendering kahâpana by rupee, as is done in the translations of certain of the Jataka stories.

2 I have gone more fully into the subject of early Indian currency in the article referred to above. The use by one translator (Jât., II. and IV.) of rupee and anna for kahâpana and mâsaka is quite unwarranted. 
work consisting of poems by Buddhist nuns (circa B.c. 400). A girl tells how her family was oppressed by usurers, and, unable to pay the accumulating interest handed her over as slave to a travelling merchant. Again in a Jataka story, the commentarial interpretation of a gad-about wife going to folks' houses is that she makes her pretext the repaying of loans or the collecting of interest. But in the earliest of the law-books we read of not only a rate, but a legal rate of interest, viz., 5 mâshas (=mâsaka above) a month for 20 kârshâpanas (said to $=20 \approx 20$ mâshas), or 15 per cent. per annum. Other regulations concerning interest and credit follow. ${ }^{1}$

The foregoing, it is true, shows but a slight progress made on the road to a development in the "fiduciary surrogates" of" money. But I trust enough has been said on this and other: points to substantiate my plea for a reconstruction of our outline history of economic life in ancient India, and to suggest the existence of a harvest ripening for historical investigation.

C. A. F. RHYS D.̈̈vids

1 Sacred Books of the East; V.ol. II., pp: 238-41. - Elsewhere 16 mâshas go to the kahâpana: 